\title{
Comparison of the alkalinity and calcium anomaly techniques to estimate rates of net calcification
}

\author{
F. Gazeau ${ }^{1,2, *}$, L. Urbini ${ }^{1,2,3}$, T. E. Cox ${ }^{1,2}$, S. Alliouane ${ }^{1,2}$, J.-P. Gattuso ${ }^{1,2}$ \\ ${ }^{1}$ Sorbonne Universités, UPMC Univ Paris 06, UMR 7093, Laboratoire d'Océanographie de Villefranche (LOV), \\ Observatoire Océanologique, Villefranche-sur-mer 06230, France \\ ${ }^{2}$ CNRS, UMR 7093, Laboratoire d'Océanographie de Villefranche (LOV), Observatoire Océanologique, \\ Villefranche-sur-mer 06230, France \\ ${ }^{3}$ Università degli Studi di Genova (DiSTAV), Corso Europa 26, Genova 16132, Italy
}

\begin{abstract}
Among current methods used to estimate calcification rates, the alkalinity anomaly technique has been widely used for short-term incubations as it is nondestructive and is based on a parameter that is easily and accurately measured. However, total alkalinity is also influenced by other processes such as nutrient consumption and release, and may also require corrections. The calcium anomaly technique has been little used because calcium is notoriously difficult to measure precisely and several species precipitate calcite with varying contents of magnesium. In this study, calcification rates of benthic calcifiers - a crustose coralline alga, a coral, a sea urchin, and a mussel-were estimated with these 2 approaches. Rates derived using the 2 methods were well correlated for all species and did not significantly differ from each other for corals incubated in the light and dark, and for coralline algae when incubated in the dark. Coralline algae appear to produce magnesian calcite in the light. Sea urchins and mussels released relatively large amounts of ammonia, and a correction of the alkalinity anomaly method was necessary. For urchins, calcification rates based on total alkalinity were higher than rates based on calcium as these organisms incorporate magnesium. For mussels, the corrected alkalinity anomaly technique provided values close to those based on calcium anomaly at low incubation densities, but values were significantly lower at high calcification and excretion rates, suggesting that ammonium concentrations were underestimated or another process affected total alkalinity. The results demonstrate that the alkalinity and calcium anomaly techniques are not robustly applicable to all calcifiers without careful consideration of organism physiology and mineralogy.
\end{abstract}

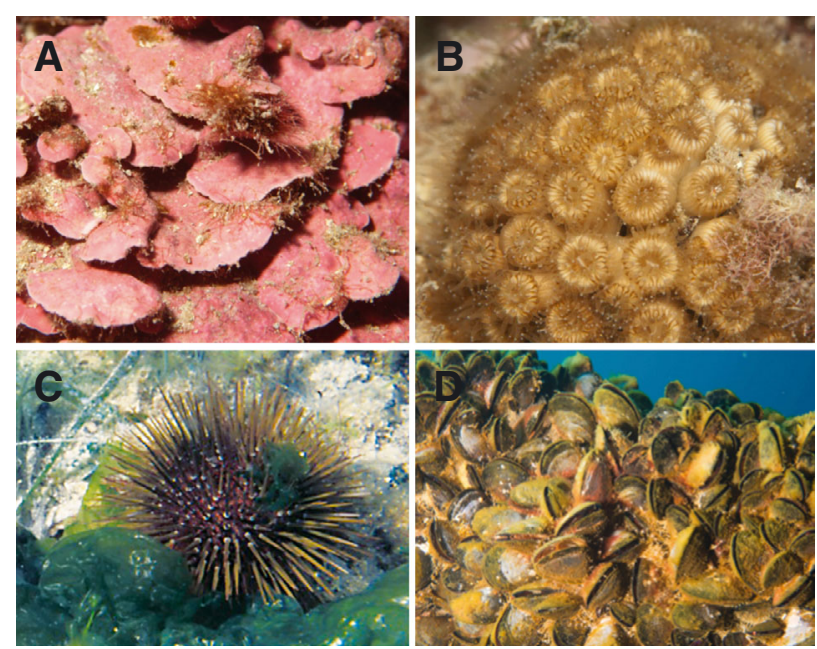

Calcification rates in 4 benthic calcifiers with distinct metabolism were determined by both the alkalinity and calcium anomaly techniques: (A) coralline alga, (B) scleractinian coral, (C) sea urchin, (D) mussel.

Photos: D. Luquet (OOV)

KEY WORDS: Calcification $\cdot$ Benthic species $\cdot$ Total alkalinity $\cdot$ Calcium $\cdot$ Methods

$$
\begin{gathered}
\text { Resale or republication not permitted without } \\
\text { written consent of the publisher }
\end{gathered}
$$

\section{INTRODUCTION}

Calcification is the biomineralization process by which some organisms produce skeletons or shells made of calcium carbonate $\left(\mathrm{CaCO}_{3}\right)$. It plays a major role in the global carbon cycle over different time scales (Milliman 1993) and is the key mechanism by which $\mathrm{CO}_{2}$ is returned to the atmosphere (Berner et 
al. 1983). The capacity of marine organisms to produce $\mathrm{CaCO}_{3}$ and its response to environmental drivers have been the subject of a growing body of research in the past decades. Indeed, oceanic carbonate chemistry is modified as a consequence of anthropogenic $\mathrm{CO}_{2}$ emissions in the atmosphere and the absorption of a significant part of them by the ocean (25\%; Le Quéré et al. 2009). Decreases in $\mathrm{pH}$ and carbonate ion concentrations $\left(\left[\mathrm{CO}_{3}{ }^{2-}\right]\right)$ and increases in $\mathrm{CO}_{2}$ and bicarbonate concentrations $\left(\left[\mathrm{HCO}_{3}{ }^{-}\right]\right)$have been observed; all these changes are collectively referred to as ocean acidification (Gattuso \& Hansson 2011). Since calcification is believed to be dependent, to some extent, on environmental $\left[\mathrm{CO}_{3}{ }^{2-}\right]$ (Broecker \& Takahashi 1966), ocean acidification often leads to decreased calcification (Kroeker et al. 2013) and may weaken the global carbonate counter-pump in the coming decades (Gehlen et al. 2007).

Several methods are available to quantify calcification rates of planktonic and benthic calcifiers. The buoyant weight technique consists of weighing an organism before and after a certain amount of time in seawater of a known density (calculated using salinity and temperature; Spencer Davies 1989). It assumes that soft tissues (including organics contained in the calcified structures) have a density close to that of seawater. It is nondestructive and offers the possibility of studying the same organism and following its calcification over time (e.g. Martin \& Gattuso 2009, Bramanti et al. 2013, Gazeau et al. 2014). Another option is to estimate the linear extension (growth) of an organism, assuming the density of its calcifying structures is known. The use of this method seems to have been limited to zooxanthellate corals (Chalker et al. 1985). Changes in the concentration of particulate inorganic carbon (e.g. Riebesell et al. 2000) and calcium (e.g. Gazeau et al. 2011) as well as the incorporation of their radioactive isotopes $\left({ }^{45} \mathrm{Ca}\right.$, Goreau \& Bowen $1955 ;{ }^{14} \mathrm{C}$, Paasche 1963) in $\mathrm{CaCO}_{3}$ have also been used. These techniques involve incubations in seawater with or without ${ }^{45} \mathrm{Ca}$ or ${ }^{14} \mathrm{C}$. The organism must subsequently be sacrificed and the skeletal components dissolved in acid to measure $\mathrm{C}, \mathrm{Ca}^{2+},{ }^{14} \mathrm{C}$ or ${ }^{45} \mathrm{Ca}$. A very attractive alternative to these destructive methods is the quantification of the change in a seawater constituent that is closely related to calcification.

The alkalinity anomaly technique (Smith \& Key 1975) has been widely used in short-term incubations or in situ studies to estimate net calcification of organisms and communities, especially of corals and coral reef environments. Total alkalinity $\left(A_{\mathrm{T}}\right)$ can be defined as the total buffering capacity of seawater, or the excess of proton acceptors over proton donors (Wolf-Gladrow et al. 2007):

$$
\begin{aligned}
A_{\mathrm{T}}= & {\left[\mathrm{HCO}_{3}{ }^{-}\right]+2\left[\mathrm{CO}_{3}{ }^{2-}\right]+\left[\mathrm{B}(\mathrm{OH})_{4}{ }^{-}\right]+\left[\mathrm{OH}^{-}\right] } \\
& +\left[\mathrm{HPO}_{4}{ }^{2-}\right]+2\left[\mathrm{PO}_{4}{ }^{3-}\right]+\left[\mathrm{H}_{3} \mathrm{SiO}_{4}{ }^{-}\right] \\
& +\left[\mathrm{NH}_{3}\right]+\left[\mathrm{HS}^{-}\right]-\left[\mathrm{HSO}_{4}{ }^{-}\right]-\left[\mathrm{H}^{+}\right]-[\mathrm{HF}] \\
& -\left[\mathrm{H}_{3} \mathrm{PO}_{4}\right]+[\text { minor acids }- \text { minor bases }]
\end{aligned}
$$

As can be seen in Eq. (1), $A_{\mathrm{T}}$ is highly influenced by $\left[\mathrm{HCO}_{3}{ }^{-}\right]$and $\left[\mathrm{CO}_{3}{ }^{2-}\right]$ together with a multitude of other minor compounds. Calcification consumes carbonate or bicarbonate, following the reversible reaction:

$$
\mathrm{Ca}^{2+}+2 \mathrm{HCO}_{3}^{-} \leftrightharpoons \mathrm{CaCO}_{3}+\mathrm{CO}_{2}+\mathrm{H}_{2} \mathrm{O}
$$

Eq. (2) shows that calcification consumes 2 moles of $\mathrm{HCO}_{3}{ }^{-}$, therefore decreasing $A_{\mathrm{T}}$ by 2 moles per mole of $\mathrm{CaCO}_{3}$ produced (see Eq. 1). It is possible to derive the rate of net calcification (gross calcification - dissolution) by measuring $A_{\mathrm{T}}$ before and after incubating an organism or a community. This method assumes, however, that only calcification influences $A_{\mathrm{T}}$ (Smith \& Key 1975). Natural water samples contain various acid-base systems that can accept and donate protons (Wolf-Gladrow et al. 2007). For instance, nitrogen assimilation through photosynthetic activities has been experimentally shown to significantly impact $A_{\mathrm{T}}$ (Brewer \& Goldman 1976). Aerobic and anaerobic (denitrification, sulphate reduction) remineralization of organic matter as well as nitrification are known to impact $A_{\mathrm{T}}$ through the consumption or release of nutrients (ammonium, nitrate and phosphate) and protons (Wolf-Gladrow et al. 2007). Although some potential limitations of the alkalinity anomaly technique were highlighted long ago (Chisholm \& Barnes 1998, Smith \& Key 1975), many different studies have made use of this method to estimate calcification rates of isolated organisms (e.g. zooxanthellate corals, Gattuso et al. 1998; mollusks, Gazeau et al. 2007; deep-sea corals, Maier et al. 2012; coralline algae, Martin et al. 2013) as well as of coral reefs (e.g. Gattuso et al. 1999).

In contrast to $A_{\mathrm{T}}$, the concentration of calcium $\left(\mathrm{Ca}^{2+}\right)$ in seawater is only influenced by net calcification and a 1:1 relationship can be used to derive net calcification rates. The calcium anomaly technique has been used considerably less than the alkalinity anomaly method due to generally large measurement errors and large background calcium concentrations ( 10.5 mmol kg-1 at a salinity of 35). However, methods based on automatic potentiometric titrations (Lebel \& Poisson 1976) have the capability to precisely and accurately measure $\mathrm{Ca}^{2+}$ concentrations in seawater. Cao \& Dai (2011) reported a preci- 
sion of ca. $0.06 \%$. As some marine calcifiers, e.g. echinoids and coralline algae, incorporate a variable but significant amount of magnesium $\left(\mathrm{Mg}^{2+}\right)$ in their calcite, the calcium anomaly technique will likely underestimate true calcification rates for these organisms.

Smith \& Roth (cited in Smith \& Kinsey 1978) and Tambutté et al. (1995) compared the alkalinity anomaly and the ${ }^{45} \mathrm{Ca}$ techniques for measuring the calcification rates of zooxanthellate corals. They reported a similar slope between the two but the intercepts had different signs, which Tambutté et al. (1995) attributed to specificities of their ${ }^{45} \mathrm{Ca}$ method. Chisholm \& Gattuso (1991) and Murillo et al. (2014) found an excellent consistency of calcification rates measured by the alkalinity and calcium anomaly techniques for isolated zooxanthellate corals. Murillo et al. (2014) showed that the alkalinity anomaly technique provided rates that were significantly lower than those based on calcium when the whole community, including sediment, was incubated.

The objective of the present study is to evaluate the capacity of the alkalinity and calcium anomaly techniques to accurately measure calcification. Rates of calcification were measured for a coral, a crustose coralline alga, an echinoid, and a mollusk, using both approaches. For each group, the calcifying mass in incubations was varied and $\mathrm{Ca}^{2+}, A_{\mathrm{T}}$ and all parameters known to influence $A_{\mathrm{T}}$ were measured.

\section{MATERIALS AND METHODS}

Mediterranean specimens of the scleractinian coral Cladocora caespitosa, the crustose coralline alga Lithophyllum cabiochae, the sea urchin Paracentrotus lividus, and the Mediterranean mussel Mytilus galloprovincialis were collected between March and May 2014 in the Bay of Villefranche (NW Mediterranean Sea, France; $\left.43^{\circ} 40.73^{\prime} \mathrm{N}, 07^{\circ} 19.39^{\prime} \mathrm{E}\right)$. After collection, specimens were immediately transported to the Laboratoire d'Océanographie de Villefranche, cleaned of epiphytes and epibionts if necessary and kept under $\sim 30 \mu \mathrm{mol}$ photons $\mathrm{m}^{-2} \mathrm{~s}^{-1}$ in a temperature controlled room $\left(16-19^{\circ} \mathrm{C}\right)$. Sampled mussels (ca. 5.5-6 cm shell length) were separated by carefully cutting their byssal threads and sea urchins were 5-8 cm in test diameter. The holding tanks received a continuous flow of external seawater pumped from a depth of $8 \mathrm{~m}$ (temperature: $16-18^{\circ} \mathrm{C}$, salinity: $\sim 38$ ).

Within 2-4 d of collection, organisms were incubated in 51 glass beakers previously cleaned with $10 \% \mathrm{HCl}$ and rinsed with filtered seawater. Six beakers were filled with filtered $(1 \mu \mathrm{m})$ seawater, gently bubbled with external air and mixed using a magnetic stirrer. Four of the 6 beakers were used to incubate the organisms, one was used to directly sample for initial conditions ( $t_{\mathrm{o}}$ hereafter), and another one was incubated without any organisms (the blank). In order to obtain a relatively wide range of calcification rates, incubations were conducted with various densities or masses of organisms (see Table 1). For corals and coralline algae, only the total incubated masses are reported in Table 1 due to the large variation in the sizes of the different pieces incubated. Mussels and sea urchins were incubated in darkness for $24 \mathrm{~h}$, while coralline algae and corals were incubated both in the light ( $24 \mathrm{~h}$ under $\sim 50 \mu \mathrm{mol}$ photons $\mathrm{m}^{-2} \mathrm{~s}^{-1}$ ) and in the dark (48 h). For each species, 2 series of incubations were conducted, leading to a sample size of 8 (i.e. 4 beakers with organisms $\times$ 2 series of incubations).

Before (in the $t_{0}$ beaker) and after incubation (in all beakers), samples were taken for the measurement of dissolved inorganic carbon $\left(C_{\mathrm{T}}\right)$, total alkalinity $\left(A_{\mathrm{T}}\right)$, calcium $\left(\mathrm{Ca}^{2+}\right)$, ammonium $\left(\mathrm{NH}_{4}^{+}\right)$, nitrate + nitrite $\left(\mathrm{NO}_{3}{ }^{-}+\mathrm{NO}_{2}{ }^{-}\right)$and phosphate $\left(\mathrm{PO}_{4}{ }^{3-}\right)$. Samples for $C_{\mathrm{T}}$ $(60 \mathrm{ml})$ were immediately poisoned with $100 \mu \mathrm{l}$ of a saturated solution of mercuric chloride $\left(\mathrm{HgCl}_{2}\right)$ and analyzed within $2 \mathrm{~d}$ using an AIRICA (Automated Infra Red Inorganic Carbon Analyzer, Marianda) coupled to a LI-COR infrared gas analyser (LI-6262), on triplicate $1.2 \mathrm{ml}$ subsamples at $22^{\circ} \mathrm{C}$. The instrument was calibrated before every set of measurements using certified reference material (CRM) from A. Dickson (Scripps Institution of Oceanography, San Diego; Batch 132). Samples for $A_{\mathrm{T}}(300 \mathrm{ml})$ were filtered on GF/F membranes (47 mm), immediately poisoned with $100 \mu \mathrm{l}$ of $\mathrm{HgCl}_{2}$ and analyzed within $2 \mathrm{~d}$. $A_{\mathrm{T}}$ was determined on triplicate $50 \mathrm{ml}$ subsamples by potentiometric titration on a titrator (Titrando 888, Metrohm) coupled to a glass electrode (ecotrode plus, Metrohm) and a thermometer (pt1000). The pH electrode was calibrated daily on the total scale using Tris buffers of salinity 38 (salinity of the seawater used during the experiment). Measurements were carried out at $22^{\circ} \mathrm{C}$ and $A_{\mathrm{T}}$ was calculated as described by Dickson et al. (2007). During the experiment, standards provided by A. Dickson (Batch 132) were used to check precision (the SD within measurements of the same batch) and accuracy (deviation from the certified value provided by Dickson. Both precision and accuracy were $1.3 \mu \mathrm{mol} \mathrm{kg} \mathrm{kg}^{-1}(\mathrm{n}=11)$. Samples for $\mathrm{Ca}^{2+}(100 \mathrm{ml})$ were filtered on $\mathrm{GF} / \mathrm{F}$ membranes (47 $\mathrm{mm}$ ) and kept in the refrigerator pending analysis (within $4 \mathrm{~d}$ ). In the laboratory, $\mathrm{Ca}^{2+}$ was determined in 
triplicate using the classic ethylene glycol tetraacetic acid (EGTA) potentiometric titration (Lebel \& Poisson 1976). Approximately $10 \mathrm{~g}$ of seawater and $10 \mathrm{~g}$ of $\mathrm{HgCl}_{2}$ solution $\left(\sim 1 \mathrm{mmol} \mathrm{l}^{-1}\right)$ were accurately weighed out; then $\sim 10 \mathrm{~g}$ of a concentrated EGTA solution $(\sim 10$ mmol $1^{-1}$, also by weighing) was added to completely complex $\mathrm{Hg}^{2+}$ and to complex nearly $95 \%$ of $\mathrm{Ca}^{2+}$. After adding $10 \mathrm{ml}$ of borate buffer $\left(\mathrm{pH}_{\mathrm{NBS}} \sim 10\right)$ to increase the $\mathrm{pH}$ of the solution, the remaining $\mathrm{Ca}^{2+}$ was titrated with a diluted solution of EGTA $\left(\sim 2 \mathrm{mmol}^{-1}\right)$ using a titrator (Titrando 888) coupled to an amalgamated silver combined electrode (Ag Titrode, Metrohm). Following Cao \& Dai (2011), the volume of EGTA necessary to titrate the remaining $\sim 5 \%$ of $\mathrm{Ca}^{2+}$ was obtained by manually fitting a polynomial function to the first derivative of the titration curve using the R software (R Core Team 2014). The EGTA solution was calibrated prior to each measurement series using IAPSO (International Association for the Physical Sciences of the Oceans ) standard seawater (Batch P147, Salinity: 35). $\mathrm{NH}_{4}{ }^{+}$concentrations were measured using 2 different methods, depending on the expected concentrations. For the coral and coralline alga, they were measured in triplicate using a colorimetric technique (Holmes et al. 1999) and a laboratory fluorometer (Trilogy). For the mussel and sea urchin, for which higher concentrations were expected after incubation, unfiltered samples $(60 \mathrm{ml})$ were immediately frozen at $-20^{\circ} \mathrm{C}$ and measured on an autoanalyser (AA3 HR, Seal Analytical) at the Institute of Marine Science (Barcelona, Spain). Samples for the determination of $\mathrm{NO}_{3}{ }^{-}+\mathrm{NO}_{2}{ }^{-}$and $\mathrm{PO}_{4}{ }^{3-}(60 \mathrm{ml})$ were also immediately frozen and measured using an autoanalyser (AA3 HR, Seal Analytical) at the Laboratoire d'Océanographie de Villefranche.

Calcification rates $\left(\mathrm{G}_{A_{\mathrm{T}}}\right)$ were estimated based on the alkalinity anomaly method, assuming that only net calcification affects $A_{\mathrm{T}}$ following the equation:

$$
\mathrm{G}_{A_{\mathrm{T}}}=-\frac{\Delta A_{\mathrm{T}}}{2}
$$

Corrected calcification rates $\left(\mathrm{G}_{A_{\mathrm{T}}}^{*}\right)$ were estimated by considering that $A_{\mathrm{T}}$ is impacted by other processes. It was assumed that (1) the assimilation and remineralization of $1 \mathrm{~mol}$ of $\mathrm{NH}_{4}{ }^{+}\left(\Delta \mathrm{NH}_{4}{ }^{+}\right)$respectively lead to a decrease and an increase of $1 \mathrm{~mol}$ of $A_{\mathrm{T}}$ (2) the assimilation and remineralization of $1 \mathrm{~mol}$ of $\mathrm{NO}_{3}{ }^{-}+\mathrm{NO}_{2}{ }^{-}\left(\Delta\left(\mathrm{NO}_{3}{ }^{-}+\mathrm{NO}_{2}{ }^{-}\right)\right)$respectively lead to an increase and a decrease of $1 \mathrm{~mol}$ of $A_{\mathrm{T}}$, and (3) the assimilation and remineralization of $1 \mathrm{~mol}$ of $\mathrm{PO}_{4}{ }^{3-}$ $\left(\Delta \mathrm{PO}_{4}{ }^{3-}\right)$ respectively lead to an increase and a decrease of $1 \mathrm{~mol}$ of $A_{\mathrm{T}}$. Therefore, $\mathrm{G}_{A_{\mathrm{T}}}$ was estimated following the equation:

$$
\mathrm{G}_{A_{\mathrm{T}}}^{*}=\frac{\Delta \mathrm{NH}_{4}^{+}-\Delta A_{\mathrm{T}}-\Delta \mathrm{NO}_{\mathrm{X}}-\Delta \mathrm{PO}_{4}{ }^{3-}}{2}
$$

Finally, calcification rates $\left(\mathrm{G}_{\mathrm{Ca}}\right)$ based on calcium variations $\left(\Delta \mathrm{Ca}^{2+}\right)$ were estimated following an inverse 1:1 relationship:

$$
\mathrm{G}_{\mathrm{Ca}}=-\Delta \mathrm{Ca}^{2+}
$$

The carbonate chemistry was assessed using $C_{\mathrm{T}}$ and $A_{\mathrm{T}}$ and the $\mathrm{R}$ package seacarb (Lavigne et al. 2014). As most of the measured parameters have associated analytical errors (i.e. SDs from triplicate measurements), combined errors associated with the estimation of rates of change between $t_{0}$ and $t_{\mathrm{f}}$ (e.g. $\Delta A_{\mathrm{T}}$ ) as well as with the estimation of $\mathrm{G}^{*}{ }_{A_{\mathrm{T}}}$ were calculated as: $S E_{x-y}=\sqrt{S E_{x}^{2}+S E_{y}^{2}}$. Model-II linear regressions (Sokal \& Rohlf 1995) were used to compare net calcification rates obtained with the different methods. All regressions were performed using the R software (R Core Team 2014).

\section{RESULTS}

Environmental conditions during the incubations are shown in Table 1. For each species, 7 to 8 incubations were conducted, with a large range of incubated mass. All incubations were conducted under carbonate chemistry favorable to calcification, as shown by the lowest seawater saturation state with respect to aragonite measured during our experiment of 1.6. SDs associated with triplicate measurements of $A_{\mathrm{T}}$ and $\mathrm{Ca}^{2+}$ are presented in Fig. 1. SDs averaged 0.74 and $3.01 \mu \mathrm{mol} \mathrm{kg}{ }^{-1}$ for $A_{\mathrm{T}}$ and $\mathrm{Ca}^{2+}$, respectively ( $\mathrm{n}=76$ ), corresponding to similar averaged CVs of $\sim 0.03 \%$.

The ranges of $\Delta A_{\mathrm{T}}, \Delta \mathrm{Ca}^{2+}, \Delta \mathrm{NH}_{4}{ }^{+}$and $\Delta \mathrm{PO}_{4}{ }^{3-}$ observed during the incubations for each species are shown in Table 2. For all parameters, the changes observed for blank incubations were several orders of magnitude lower than those observed with organisms (data not shown). For all species, $A_{\mathrm{T}}$ and $\mathrm{Ca}^{2+}$ concentrations decreased during the incubations. The largest decreases in $A_{\mathrm{T}}$ and $\mathrm{Ca}^{2+}$ were observed for mussels $\left(A_{\mathrm{T}}\right.$ : -582 and $\mathrm{Ca}^{2+}:-412 \mu \mathrm{mol} \mathrm{kg} \mathrm{kg}^{-1}$, corresponding to 267 and $580 \mathrm{~g}$ of mussels incubated). For the coral and the coralline alga, $\Delta \mathrm{NH}_{4}{ }^{+}, \Delta\left(\mathrm{NO}_{3}{ }^{-}+\mathrm{NO}_{2}{ }^{-}\right)$ and $\Delta \mathrm{PO}_{4}{ }^{3-}$ were always more than 2 orders of magnitude lower than $\Delta A_{\mathrm{T}}$ and $\Delta \mathrm{Ca}^{2+}$ (Table 2). Note that $\Delta\left(\mathrm{NO}_{3}{ }^{-}+\mathrm{NO}_{2}{ }^{-}\right)$and $\Delta \mathrm{PO}_{4}{ }^{3-}$ could not be measured for the coral incubated in the dark. The processes impacting $\mathrm{NH}_{4}{ }^{+}, \mathrm{NO}_{3}{ }^{-}+\mathrm{NO}_{2}{ }^{-}$and $\mathrm{PO}_{4}{ }^{3-}$ contributed $<2 \%$ of observed $\Delta A_{\mathrm{T}}$ (Table 3 ). 
Table 1. Environmental conditions during the incubations (8 incubations per species, except for corals in the light: $\mathrm{n}=7$ ). Ranges are presented for (min - max) of temperature $(\mathrm{T})$, dissolved inorganic carbon $\left(C_{\mathrm{T}}\right)$, total alkalinity $\left(A_{\mathrm{T}}\right)$, pH on the total scale $(\mathrm{pH}$ of $\mathrm{CO}_{2}\left(p \mathrm{CO}_{2}\right)$, and saturation states with respect to aragonite $\left(\Omega_{\text {Aragonite }}\right)$ and calcite $\left(\Omega_{\mathrm{Calcite}}\right)$. pH $\mathrm{H}_{\mathrm{T}}$ and $p \mathrm{CO} \mathrm{O}_{2}$ were calculated at ambient temperature. Incubation times and the ranges of incubated mass (fresh weights) are also reported. Salinity was $\sim 38$

\begin{tabular}{|c|c|c|c|c|c|c|c|c|c|c|}
\hline Species & $\begin{array}{l}\text { Incubation } \\
\text { time (h) }\end{array}$ & $\begin{array}{c}\text { Incubated } \\
\text { density (ind.) }\end{array}$ & $\begin{array}{c}\text { Incubated } \\
\text { mass (g) }\end{array}$ & $\begin{array}{c}\mathrm{T} \\
\left({ }^{\circ} \mathrm{C}\right)\end{array}$ & $\begin{array}{c}C_{\mathrm{T}} \\
\left(\mu \mathrm{mol} \mathrm{kg}{ }^{-1}\right)\end{array}$ & $\begin{array}{c}A_{\mathrm{T}} \\
(\mu \mathrm{mol} \mathrm{kg})\end{array}$ & $\mathrm{pH}_{\mathrm{T}}$ & $\begin{array}{l}p \mathrm{CO}_{2} \\
(\mu \mathrm{atm})\end{array}$ & $\Omega_{\text {Aragonite }}$ & $\Omega_{\text {Calcite }}$ \\
\hline \multicolumn{11}{|l|}{ C. caespitosa (coral) } \\
\hline Light & 24 & - & $126-816$ & $16.8-19.0$ & $2187-2275$ & $2346-2524$ & $8.0-8.1$ & $317-563$ & $2.4-3.3$ & $3.8-5.1$ \\
\hline Dark & 48 & - & $96-677$ & $16.0-17.0$ & $2282-2325$ & $2464-2533$ & $7.8-8.0$ & $572-723$ & $2.1-2.5$ & $3.2-3.8$ \\
\hline \multicolumn{11}{|c|}{ L. cabiochae (coralline alga) } \\
\hline Light & 24 & - & $29-249$ & $16.1-18.2$ & $2041-2224$ & $2273-2511$ & $8.0-8.1$ & $412-473$ & $2.5-3.1$ & $3.8-4.8$ \\
\hline Dark & 48 & - & $40-213$ & $17.2-18.2$ & $2247-2360$ & $2453-2534$ & $7.9-8.0$ & $460-660$ & $2.2-2.8$ & $3.5-4.4$ \\
\hline P. lividus (sea urchin) & 24 & $1-5$ & $39-190$ & $16.0-16.2$ & $2274-2343$ & $2419-2558$ & $7.8-8.0$ & $551-892$ & $1.8-2.5$ & $2.8-3.8$ \\
\hline $\begin{array}{l}\text { M. galloprovincialis } \\
\text { (mussel) }\end{array}$ & 24 & $5-80$ & $59-580$ & $15.9-18.2$ & $2151-2299$ & $2299-2485$ & $7.6-7.9$ & $670-1379$ & $1.6-2.1$ & $2.4-3.3$ \\
\hline
\end{tabular}

The uncorrected or corrected alkalinity anomaly $\left(\mathrm{G}_{A_{\mathrm{T}}}\right.$ or $\left.\mathrm{G}_{A_{\mathrm{T}}}^{*}\right)$ and calcium anomaly $\left(\mathrm{G}_{\mathrm{Ca}}\right)$ techniques provided similar calcification rates and no statistical differences between rates were found for the coral incubated in the light and in the dark (Table 4, Fig. 2). Similar results were obtained for the crustose coralline alga incubated in the dark with a 1:1 relationship between the estimates. However, for the coralline alga incubated in the light, $\mathrm{G}_{A_{\mathrm{T}}}$ and $\mathrm{G}^{*}{ }_{\mathrm{T}}$ were significantly higher than $\mathrm{G}_{\mathrm{Ca}}$ (Table 4, Fig. 2).

In contrast to the coral and coralline alga, the mussel and the sea urchin were significant sources of ammonium during the incubations. $\Delta \mathrm{NH}_{4}{ }^{+}$was of the same order of magnitude as $\Delta A_{\mathrm{T}}$ and $\Delta \mathrm{Ca}^{2+}$ (Table 2). In both species, $\mathrm{NH}_{4}{ }^{+}$release through excretion was the second most important process affecting $A_{\mathrm{T}}$, representing $36.2 \pm 6.3$ and $17.1 \pm 2.6 \%$ of $\Delta A_{\mathrm{T}}$ for the

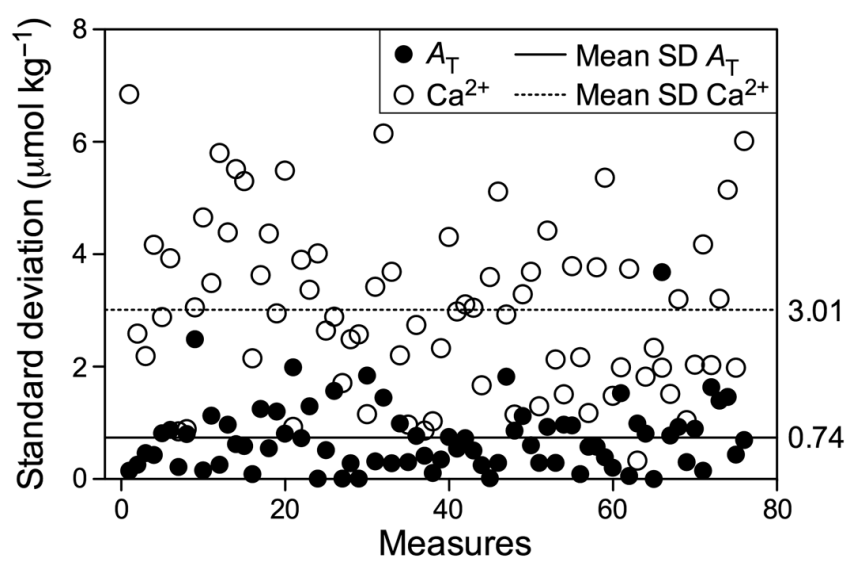

Fig. 1. SDs of triplicate measurements of total alkalinity $\left(A_{\mathrm{T}}\right)$ and calcium $\left(\mathrm{Ca}^{2+}\right)$ for all measurements $(\mathrm{n}=76)$. Horizontal lines are mean SDs $(\mathrm{n}=76)$ for $A_{\mathrm{T}}(-)$ and $\mathrm{Ca}^{2+}(---)$ sea urchin and the mussel, respectively (Table 3). Variations in $\mathrm{NO}_{3}{ }^{-}+\mathrm{NO}_{2}{ }^{-}$and $\mathrm{PO}_{4}{ }^{3-}$ contributed $0.1 \pm$ 0.1 to $1.8 \pm 0.6 \%$ of $\Delta A_{\mathrm{T}}$. For the sea urchin, calcification rates as estimated by the alkalinity anomaly technique without any correction provided slightly different values than $\mathrm{G}_{\mathrm{Ca}}$ (Fig. 3, Table 4). After correction for nutrient variations, $\mathrm{G}^{*}{ }_{\mathrm{T}}$ values were significantly higher than $\mathrm{G}_{\mathrm{Ca}}$. For the mussel, estimates based on the alkalinity anomaly technique provided rates that were significantly lower than those estimated by the calcium anomaly technique (Fig. 3, Table 4). For the lowest range of densities and calcification rates $\left(<200 \mu \mathrm{mol} \mathrm{kg} \mathrm{kg}^{-1}\right)$, the correction applied to the alkalinity anomaly technique led to rates that were similar to the ones based on calcium. At higher densities and calcification rates

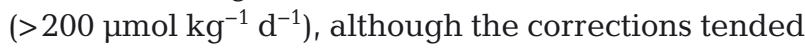
to move calcification rates closer to values estimated using the calcium anomaly method, calcification rates were still significantly lower than rates based on calcium (Fig. 3).

\section{DISCUSSION}

Significant changes in $A_{\mathrm{T}}$ and $\mathrm{Ca}^{2+}$ were observed during incubations of the 4 species considered and at all abundances. For the coral, results are consistent with previous studies that reported very small impacts of nutrient consumption and release on $A_{\mathrm{T}}$ and no significant differences between rates of calcification estimated using the alkalinity and calcium anomaly techniques (Chisholm \& Gattuso 1991, Murillo et al. 2014). Note that Murillo et al. (2014) found that calcification rates estimated by the alkalinity anomaly technique were significantly lower 
Table 2. Amplitude of changes ( $\mu \mathrm{mol} \mathrm{kg}{ }^{-1} t^{-1} ; t=24 \mathrm{~h}$ in the light and $48 \mathrm{~h}$ in the dark) in total alkalinity $\left(\Delta A_{\mathrm{T}}\right), \mathrm{calcium}\left(\Delta \mathrm{Ca}{ }^{2+}\right)$, ammonium $\left(\Delta \mathrm{NH}_{4}{ }^{+}\right)$, nitrate+nitrite $\left(\Delta\left(\mathrm{NO}_{3}{ }^{-}+\mathrm{NO}_{2}{ }^{-}\right)\right)$and phosphate $\left(\Delta \mathrm{PO}_{4}{ }^{3-}\right)$ observed during the incubations (8 incubations per species, except for the coral in the light: $n=7$ ). NA: not available

\begin{tabular}{|c|c|c|c|c|c|c|c|c|c|c|c|}
\hline \multirow[t]{2}{*}{ Species } & & \multicolumn{2}{|c|}{$\Delta A_{\mathrm{T}}$} & \multicolumn{2}{|c|}{$\Delta \mathrm{Ca}^{2+}$} & \multicolumn{2}{|c|}{$\Delta \mathrm{NH}_{4}^{+}$} & \multicolumn{2}{|c|}{$\Delta\left(\mathrm{NO}_{3}^{-}+\mathrm{NO}_{2}^{-}\right)$} & \multicolumn{2}{|c|}{$\Delta \mathrm{PO}_{4}{ }^{3-}$} \\
\hline & & Max & Min & $\operatorname{Max}$ & Min & $\begin{array}{l}\operatorname{Max}_{\Delta<0} \\
\operatorname{Min}_{\Delta>0}\end{array}$ & Max & $\begin{array}{l}\operatorname{Max}_{\Delta<0} \\
\operatorname{Min}_{\Delta>0}\end{array}$ & Max & $\begin{array}{l}\operatorname{Max}_{\Delta<0} \\
\operatorname{Min}_{\Delta>0}\end{array}$ & Max \\
\hline C. caespitosa (coral) & $\begin{array}{l}\text { Light } \\
\text { Dark }\end{array}$ & $\begin{array}{l}-415 \\
-172\end{array}$ & $\begin{array}{l}-59 \\
-28\end{array}$ & $\begin{array}{l}-189 \\
-68\end{array}$ & $\begin{array}{l}-38 \\
-9\end{array}$ & $\begin{array}{r}-0.1 \\
0.5\end{array}$ & $\begin{array}{l}2.7 \\
3.0\end{array}$ & $\begin{array}{l}-4.0 \\
\text { NA }\end{array}$ & $\begin{array}{l}4.0 \\
\text { NA }\end{array}$ & $\begin{array}{l}-0.1 \\
\text { NA }\end{array}$ & $\begin{array}{r}0.0 \\
\text { NA }\end{array}$ \\
\hline $\begin{array}{l}\text { L. cabiochae } \\
\text { (coralline alga) }\end{array}$ & $\begin{array}{l}\text { Light } \\
\text { Dark }\end{array}$ & $\begin{array}{l}-577 \\
-187\end{array}$ & $\begin{array}{r}-100 \\
-69\end{array}$ & $\begin{array}{l}-218 \\
-90\end{array}$ & $\begin{array}{l}-23 \\
-16\end{array}$ & $\begin{array}{l}-0.4 \\
-0.6\end{array}$ & $\begin{array}{l}0.7 \\
2.7\end{array}$ & $\begin{array}{l}-1.5 \\
-0.7\end{array}$ & $\begin{array}{l}0.2 \\
1.8\end{array}$ & $\begin{array}{l}-0.2 \\
-0.1\end{array}$ & $\begin{array}{l}0.1 \\
0.4\end{array}$ \\
\hline P. lividus (sea urchin) & & -293 & -3 & -151 & -13 & 80 & 159 & -0.8 & 0.9 & -0.8 & 1.4 \\
\hline $\begin{array}{l}\text { M. galloprovincialis } \\
\text { (mussel) }\end{array}$ & & -582 & -194 & -412 & -111 & 33 & 182 & 0.4 & 12 & 5.4 & 22 \\
\hline
\end{tabular}

Table 3. Contribution $(\% \pm \mathrm{SE})$ of the considered processes to observed variation in total alkalinity. $\Delta \mathrm{NH}_{4}{ }^{+}, \Delta\left(\mathrm{NO}_{3}{ }^{-}+\mathrm{NO}_{2}{ }^{-}\right)$, $\Delta \mathrm{PO}_{4}{ }^{3-}$ : assimilation or remineralization of ammonium, nitrate+nitrite and phosphate, respectively. G: net calcification. NA: not available

\begin{tabular}{|lccccc|}
\hline Species & & $\Delta \mathrm{NH}_{4}{ }^{+}$ & $\Delta\left(\mathrm{NO}_{3}{ }^{-}+\mathrm{NO}_{2}{ }^{-}\right)$ & $\Delta \mathrm{PO}_{4}{ }^{3-}$ & $\mathrm{G}$ \\
\hline C. caespitosa (coral) & Dark & $1.9 \pm 2.1$ & $\mathrm{NA}$ & $\mathrm{NA}$ & $98.1 \pm 2.1$ \\
& Light & $0.5 \pm 0.7$ & $1.2 \pm 1.0$ & $0.0 \pm 0.0$ & $98.3 \pm 1.6$ \\
L. cabiochae (coralline alga) & Dark & $0.6 \pm 0.7$ & $0.5 \pm 0.4$ & $0.1 \pm 0.1$ & $98.8 \pm 1.1$ \\
& Light & $0.2 \pm 0.1$ & $0.3 \pm 0.3$ & $0.0 \pm 0.0$ & $99.5 \pm 0.7$ \\
P. lividus (sea urchin) & Dark & $36.2 \pm 6.3$ & $0.1 \pm 0.1$ & $0.2 \pm 0.1$ & $63.6 \pm 6.3$ \\
M. galloprovincialis (mussel) & Dark & $17.1 \pm 2.6$ & $0.9 \pm 1.6$ & $1.8 \pm 0.6$ & $80.2 \pm 2.6$ \\
\hline
\end{tabular}

Table 4. Outputs of the model-II regressions ( $\mathrm{n}=8$ incubations per species, except for corals in the light: $\mathrm{n}=7$ ) between net calcification rates derived from the alkalinity anomaly technique (uncorrected: $\mathrm{G}_{A_{\mathrm{T}}}$ or corrected: $\mathrm{G}_{A_{\mathrm{T}}}$ ) and the calcium anomaly technique $\left(\mathrm{G}_{\mathrm{Ca}}\right): \mathrm{G}_{A_{\mathrm{T}}}$ or $\mathrm{G}_{A_{\mathrm{T}}}^{*}=$ Slope $\pm \mathrm{SE} \times \mathrm{G}_{\mathrm{Ca}}+\mathrm{Y}$-intercept $\pm \mathrm{SE}$. p-values of Student's $t$-tests for the slope and the Y-intercept are presented. Bold values denote significant differences at $\alpha<0.05$

\begin{tabular}{|c|c|c|c|c|c|c|c|c|}
\hline & & & $\mathrm{n}$ & Slope & Y-intercept & $\begin{array}{l}\text { Slope } \neq 0 \\
\text { p-value }\end{array}$ & $\begin{array}{l}\text { Slope } \neq 1 \\
\text { p-value }\end{array}$ & $\begin{array}{c}\text { Y-intercept } \neq 0 \\
\text { p-value }\end{array}$ \\
\hline C. caespitosa (coral) & $\begin{array}{l}\text { Dark } \\
\text { Light }\end{array}$ & $\begin{array}{l}\mathrm{G}_{A_{\mathrm{T}}} \\
\mathrm{G}^{*}{ }_{A_{\mathrm{T}}} \\
\mathrm{G}_{A_{\mathrm{T}}} \\
\mathrm{G}_{A_{\mathrm{T}}}^{*}\end{array}$ & $\begin{array}{l}8 \\
8 \\
7 \\
7\end{array}$ & $\begin{array}{l}1.02 \pm 0.08 \\
1.02 \pm 0.08 \\
1.15 \pm 0.07 \\
1.15 \pm 0.07\end{array}$ & $\begin{array}{r}2.8 \pm 3.3 \\
3.4 \pm 3.3 \\
-19.1 \pm 7.8 \\
-19.4 \pm 8.1\end{array}$ & $\begin{array}{l}<0.001 \\
<0.001 \\
<0.001 \\
<0.001\end{array}$ & $\begin{array}{l}0.82 \\
0.85 \\
0.08 \\
0.09\end{array}$ & $\begin{array}{l}0.42 \\
0.34 \\
0.05 \\
0.05\end{array}$ \\
\hline L. cabiochae (coralline alga) & $\begin{array}{l}\text { Dark } \\
\text { Light }\end{array}$ & $\begin{array}{l}\mathrm{G}_{A_{\mathrm{T}}} \\
\mathrm{G}_{A_{\mathrm{T}}}^{*} \\
\mathrm{G}_{A_{\mathrm{T}}} \\
\mathrm{G}_{A_{\mathrm{T}}}^{*}\end{array}$ & $\begin{array}{l}8 \\
8 \\
8 \\
8\end{array}$ & $\begin{array}{l}1.15 \pm 0.08 \\
1.16 \pm 0.07 \\
1.18 \pm 0.08 \\
1.18 \pm 0.08\end{array}$ & $\begin{aligned}-12.1 & \pm 5.9 \\
-12.9 & \pm 5.2 \\
31.2 & \pm 10.7 \\
31.4 & \pm 10.7\end{aligned}$ & $\begin{array}{l}<0.001 \\
<0.001 \\
<0.001 \\
<0.001\end{array}$ & $\begin{array}{l}0.11 \\
0.05 \\
0.06 \\
0.06\end{array}$ & $\begin{array}{l}0.09 \\
0.05 \\
\mathbf{0 . 0 3} \\
\mathbf{0 . 0 3}\end{array}$ \\
\hline P. lividus (sea urchin) & & $\begin{array}{l}\mathrm{G}_{A_{\mathrm{T}}} \\
\mathrm{G}_{A_{\mathrm{T}}}^{*}\end{array}$ & $\begin{array}{l}8 \\
8\end{array}$ & $\begin{array}{l}1.08 \pm 0.07 \\
1.40 \pm 0.12\end{array}$ & $\begin{array}{r}-16.2 \pm 5.1 \\
21.9 \pm 8.7\end{array}$ & $\begin{array}{l}<0.001 \\
<0.001\end{array}$ & $\begin{array}{l}0.29 \\
\mathbf{0 . 0 1}\end{array}$ & $\begin{array}{l}\mathbf{0 . 0 2} \\
0.05\end{array}$ \\
\hline M. galloprovincialis (mussel) & & $\begin{array}{l}\mathrm{G}_{A_{\mathrm{T}}} \\
\mathrm{G}_{A_{\mathrm{T}}}^{*}\end{array}$ & $\begin{array}{l}8 \\
8\end{array}$ & $\begin{array}{l}0.60 \pm 0.04 \\
0.79 \pm 0.05\end{array}$ & $\begin{array}{l}32.4 \pm 12.3 \\
26.1 \pm 14.3\end{array}$ & $\begin{array}{l}<0.001 \\
<0.001\end{array}$ & $\begin{array}{r}<0.001 \\
0.005\end{array}$ & $\begin{array}{l}\mathbf{0 . 0 4} \\
0.12\end{array}$ \\
\hline
\end{tabular}

than calcium-based estimates when the whole reef community, including sediment, was considered. This discrepancy was attributed to the release of $A_{\mathrm{T}}$ from the sediment as a consequence of anaerobic mineralization processes, such as net sulphate reduc- tion and denitrification (Hu \& Cai 2011). No correction for nutrient release was necessary in our study for isolated colonies of Cladocora caespitosa and errors associated with $A_{\mathrm{T}}$ measurements were relatively low (Fig. 2). Consequently, calcification rates 

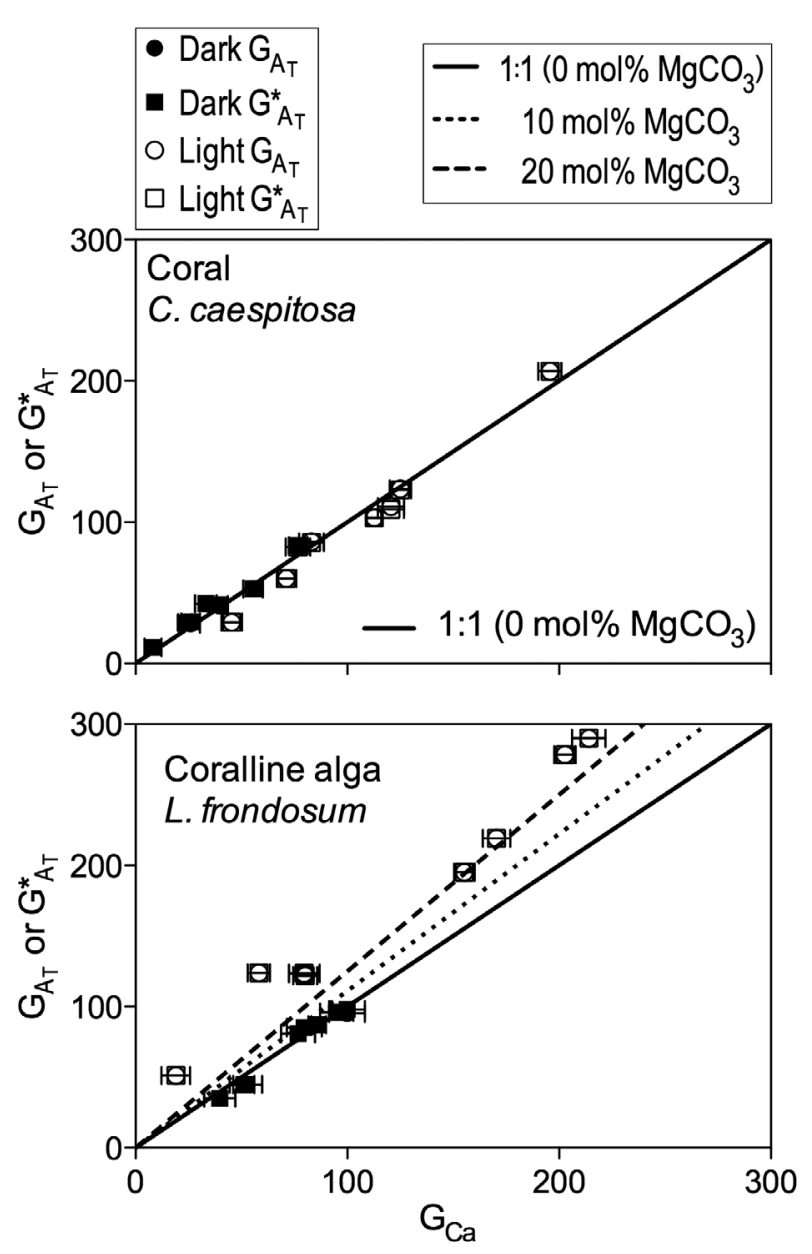

Fig. 2. Calcification rates (mean $\pm \mathrm{SE}_{i} \mu \mathrm{mol} \mathrm{kg}{ }^{-1} t^{-1} ; t=48 \mathrm{~h}$ in the dark and $24 \mathrm{~h}$ in the light) estimated based on the alkalinity anomaly technique (uncorrected: $\mathrm{G}_{A_{\mathrm{T}}}$ or corrected: $\mathrm{G}^{*}{ }_{\mathrm{T}}$ ) as a function of calcification rates estimated based on the calcium anomaly technique $\left(\mathrm{G}_{\mathrm{Ca}}\right)$ for the scleractinian coral Cladocora caespitosa (upper panel) and the crustose coralline alga Lithophyllum cabiochae (lower panel). $\mathrm{G}_{A_{T}}$ and $\mathrm{G}_{A_{\mathrm{T}}}^{*}$ are not different from each other and are superimposed. SEs for $G_{A_{T}}$ and $G_{A_{T}}^{*}$ are too small to be visible. Lines represent the theoretical relationship between $\mathrm{G}_{A_{\mathrm{T}}}$ or $\mathrm{G}_{A_{\mathrm{T}}}^{*}$ and $\mathrm{G}_{\mathrm{Ca}}$ for different contents of magnesiun in the skeleton $\left(\% \mathrm{MgCO}_{3}\right)$

could be estimated with very good precision for this species.

The average precision (SD) of $A_{\mathrm{T}}$ was $\sim 0.7 \mu \mathrm{mol}$ $\mathrm{kg}^{-1}$, which is below the precision specified by Dickson et al. (2007) for open-cell titrations $(\sim 1 \mu \mathrm{mol}$ $\mathrm{kg}^{-1}$ ). The precision of $\mathrm{Ca}^{2+}$ measurements was significantly less than for $A_{\mathrm{T}}$ (Fig. $1 ; \sim 3 \mu \mathrm{mol} \mathrm{kg} \mathrm{kg}^{-1}$ ). Since there is a theoretical 1:1 relationship between calcification and $\Delta \mathrm{Ca}^{2+}$ for organisms precipitating calcite and aragonite, the calcium anomaly technique is less efficient in measuring low rates of calcification (low calcifying mass and/or small incubation times) and in
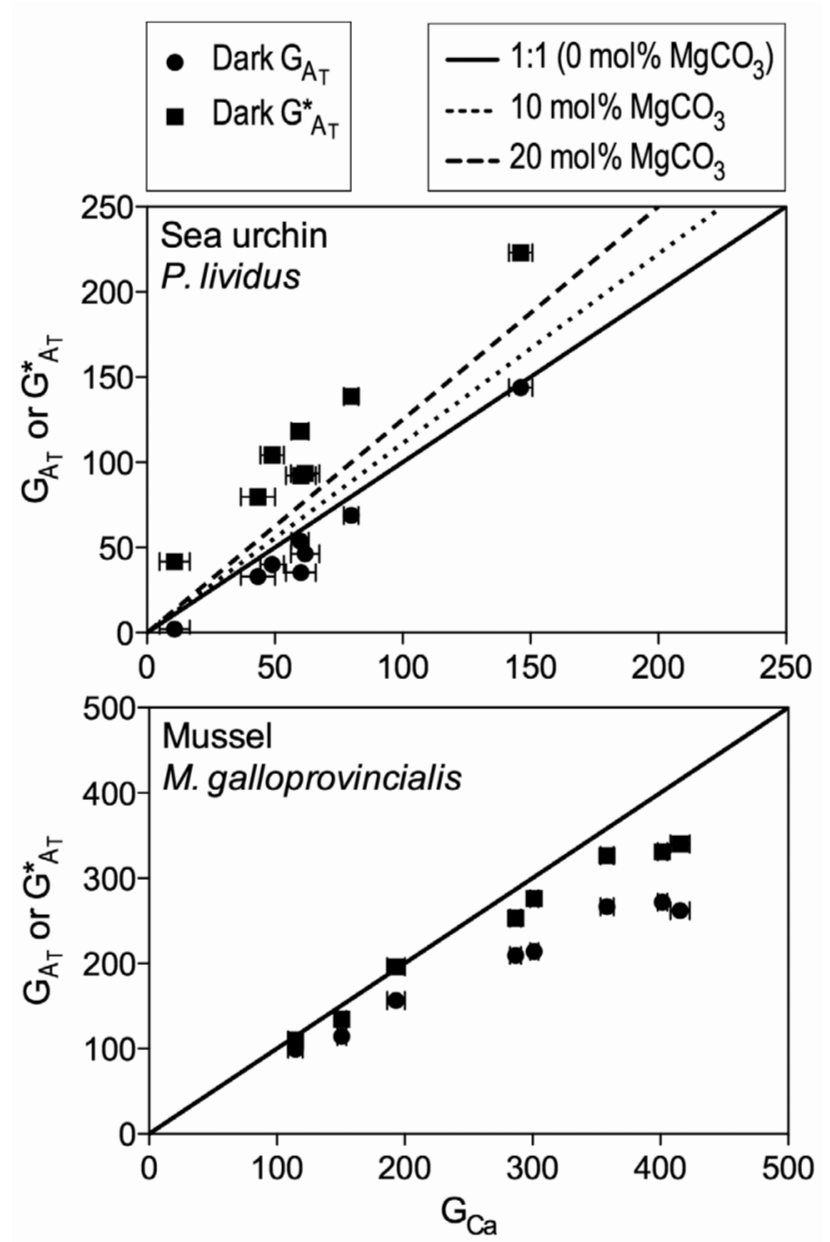

Fig. 3. Calcification rates (mean $\pm \mathrm{SE}$; $\mu \mathrm{mol} \mathrm{kg}{ }^{-1} t^{-1} ; t=24 \mathrm{~h}$ ) estimated based on the alkalinity anomaly technique (uncorrected: $\mathrm{G}_{A_{\mathrm{T}}}$ or corrected: $\mathrm{G}_{A_{\mathrm{T}}}$ ) as a function of calcification rates estimated based on the calcium anomaly technique $\left(\mathrm{G}_{\mathrm{Ca}}\right)$ for the sea urchin Paracentrotus lividus (upper panel) and the mussel Mytilus galloprovincialis (lower panel). $G_{A_{T}}$ and $G^{*}{ }_{A_{T}}$ are not different from each other and are superimposed. SEs for $\mathrm{G}_{A_{\mathrm{T}}}$ and $\mathrm{G}_{A_{\mathrm{T}}}^{*}$ are too small to be visible. Lines represent the theoretical relationship between $\mathrm{G}_{A_{\mathrm{T}}}$ or $\mathrm{G}_{A_{\mathrm{T}}}^{*}$ and $\mathrm{G}_{\mathrm{Ca}}$ for different contents of magnesium in the skeleton or shells $\left(\% \mathrm{MgCO}_{3}\right)$

capturing small differences in calcification as a consequence of varying environmental conditions, such as ocean acidification. It must be stressed that the precision reached in our study is among the highest reported for $\mathrm{Ca}^{2+}$ in seawater, using the same protocol. Indeed, Cao \& Dai (2011) reported averaged SDs of $\sim 6 \mu \mathrm{mol} \mathrm{kg} \mathrm{kg}^{-1}$, while Murillo et al. (2014), using a similar technique based on titrations with EGTA but using a $\mathrm{Ca}^{2+}$-selective electrode, reported measurement errors of $\sim 20 \mu \mathrm{mol} \mathrm{kg}{ }^{-1}$. Recently, Liu et al. (2014) reviewed available techniques for measuring $\mathrm{Ca}^{2+}$ in seawater and the precision reached in our 
study $(\sim 0.03 \%$ of relative SD) was better than all studies using a similar protocol (EGTA titration; $>0.1 \%$ ) and lower than that based on isotope dilution and inductively coupled plasma mass spectrometry (ID-ICP; $0.1 \%$ ) or thermal ionization mass spectrometry (ID-TIMS; $0.05 \%$ ). The main advantage of mass spectrometry techniques is the very low volume of sample necessary for the measurements $(\sim 10 \mu \mathrm{l}$ for ID-ICP; Liu et al. 2014). Nevertheless, following these considerations, the use of the alkalinity anomaly technique for measuring calcification rates of isolated corals appears to be a better choice, as this method allows the detection of rates of calcification or difference in calcification rates above $\sim 0.5 \mu \mathrm{mol} \mathrm{kg}{ }^{-1}$ incubation $^{-1}$, assuming robust analytical protocols.

As with the coral, the crustose coralline alga Lithophyllum cabiochae showed variations in nutrient concentrations resulting from nutrient acquisition/ release that were relatively low compared to $\Delta A_{\mathrm{T}}$; thus, no correction of the alkalinity anomaly technique was necessary. Calcification rates estimated by the 2 methods were significantly correlated. While rates were not significantly different in the dark, the alkalinity anomaly technique provided rates in the light that were significantly lower than those based on calcium anomaly. This suggests that this coralline alga produces magnesian calcite during the day, but not at night. It is well established that calcareous algae precipitate calcite with a significant proportion of $\mathrm{Mg}^{2+}$ (Diaz-Pulido et al. 2014), but to the best of our knowledge, no studies have reported such difference between calcification under light and dark conditions. The lack of net $\mathrm{Mg}^{2+}$ incorporation at night could be due to chemical conditions being less favorable for this mineral that is more soluble than 'pure' calcite. The release of $\mathrm{CO}_{2}$ through respiration and the lack of $\mathrm{CO}_{2}$ consumption through photosynthesis could lead to less favorable conditions in the immediate surrounding (diffusion boundary layer) of the coralline alga at night. Several studies have recently shown an impact of ocean acidification with or without warming on the $\mathrm{MgCO}_{3} / \mathrm{CaCO}_{3}$ ratio of coralline algae (e.g. Ries 2011, Egilsdottir et al. 2013, DiazPulido et al. 2014). Our data suggest that the response to these drivers could be modulated by irradiance, and that future experiments should cover the range of irradiance to which the coralline algae are exposed in the field. Although the slopes of the regressions between $\mathrm{G}_{A_{\mathrm{T}}}$ or $\mathrm{G}_{A_{\mathrm{T}}}$ and $\mathrm{G}_{\mathrm{Ca}}$ were not significantly different from 1 , one can see in Fig. 3 that points are close to the theoretical line for calcite containing $20 \mathrm{~mol} \%$ of $\mathrm{MgCO}_{3}$. This is slightly above the $\mathrm{MgCO}_{3}$ contents of $15 \mathrm{~mol} \%$ reported for the same species sampled at the same location by $\mathrm{S}$. Martin et al. (unpubl.). It must be stressed that the irradiance levels during our incubations were significantly higher than the levels considered by S. Martin et al. (unpubl.) (9-35 $\mu \mathrm{mol}$ photons $\mathrm{m}^{-2} \mathrm{~s}^{-1}$ ) and could explain the higher proportion of $\mathrm{MgCO}_{3}$ precipitation in our study. However, the lowest rates of calcification appeared to depart from this theoretical line, with Y-intercepts that were significantly different from 0 (Table 4). The reasons of these discrepancies remain unclear. As for the coral, overall, the alkalinity anomaly technique appears precise and accurate enough to estimate calcification rates for this species, and is especially well suited to detecting changes in calcification rates as a consequence of environmental change. In contrast, in the light, measuring $\mathrm{Ca}^{2+}$ alone without considering $\mathrm{Mg}^{2+}$ incorporation does not allow accurate estimation of net calcification rates. $\left[\mathrm{Ca}^{2+}+\mathrm{Mg}^{2+}+\right.$ strontium] can be determined in seawater by a potentiometric titration similar to the one used for $\mathrm{Ca}^{2+}$ in the present paper. The $\mathrm{Mg}^{2+}$ concentration can be obtained by difference, assuming that the strontium concentration is negligible $\left(\sim 0.2 \%\right.$ of $\mathrm{Mg}^{2+}$ concentration). However, estimating changes in $\mathrm{Mg}^{2+}$ concentrations is even more challenging than estimating changes in $\mathrm{Ca}^{2+}$ because it is based on 2 titrations, each with associated analytical errors. Furthermore, the background concentration of $\mathrm{Mg}^{2+}$ is very large, with a $\mathrm{Mg}^{2+} / \mathrm{Ca}^{2+}$ ratio of $\sim 5.2$, making detection of small changes very difficult.

In contrast to the coral and the coralline alga, changes in the concentrations of $\mathrm{NH}_{4}{ }^{+}, \mathrm{NO}_{3}{ }^{-}+\mathrm{NO}_{2}{ }^{-}$ and $\mathrm{PO}_{4}{ }^{3-}$ in the sea urchin and the mussel were important relative to net calcification and were required to correct changes in $A_{\mathrm{T}}$. Among processes involved, changes in $\mathrm{NH}_{4}{ }^{+}$concentrations were responsible for 17 to $36 \%$ of changes in $A_{\mathrm{T}}$. $\mathrm{NH}_{4}{ }^{+}$originates from the ammonification of organic waste (feces, excess food, dead animals) by heterotrophic bacteria that use these wastes as a source of nutrients. It is also generated by animal excretion and results from deamination and transamination during food digestion. Echinoids excrete urea, which is readily decomposed by ureolytic bacteria into ammonia (Basuyaux \& Mathieu 1999). In contrast, mussels are known to excrete mostly nitrogen in the form of $\mathrm{NH}_{4}{ }^{+}$(40 to $100 \%$ ), the remaining nitrogen being excreted in an organic form (Bayne \& Scullard 1977). There are very few reports on the influence of $\mathrm{NH}_{4}{ }^{+}$ excretion by echinoids and mollusks on $A_{\mathrm{T}}$. Previous experiments that focused on the effect of ocean acidification on bivalve calcification assumed that $\mathrm{NH}_{4}^{+}$ 
excretion is negligible (Gazeau et al. 2007, Mingliang et al. 2011, Waldbusser et al. 2011). Recently, however, Gazeau et al. (2014) reported $\mathrm{NH}_{4}{ }^{+}$excretion rates being responsible for $60 \%$ (on average) of $\Delta A_{\mathrm{T}}$ in the Mediterranean mussel Mytilus galloprovincialis kept in the laboratory for $\sim 1 \mathrm{yr}$. This contribution is much higher than that reported in the present study, suggesting that correction of $\Delta A_{\mathrm{T}}$ could vary significantly depending on the physiological state of the organism. In contrast to bivalves, the alkalinity anomaly technique has not been used to estimate echinoid calcification, to the best of our knowledge. So far, the buoyant weight (Ries et al. 2009) and the calcium content of calcified structures (Wood et al. 2008) have been the preferred techniques, although these are destructive and/or are applicable only over relatively long cultivation periods.

Sea urchins are also known to produce relatively large amounts of magnesian calcite (Weber 1969), explaining why calcification rates estimated based on $\mathrm{Ca}^{2+}$ anomaly were significantly lower than those obtained from changes in $A_{\mathrm{T}}$ corrected for changes in nutrients. However, the correction of the alkalinity anomaly technique led to estimates of net calcification rates much above the theoretical line considering $20 \mathrm{~mol} \%$ of $\mathrm{MgCO}_{3}$, which seems to be a high estimate for this species as a ratio of $11.8 \mathrm{~mol} \%$ has been reported for Paracentrotus lividus in the Mediterranean Sea (Hermans et al. 2010). As such, our study does not allow us to test the validity of the alkalinity technique for this species and further comparative studies should consider measuring $\mathrm{Mg}^{2+}$ incorporation rates.

In the mussel, in addition to changes in $\mathrm{NH}_{4}{ }^{+}$concentrations, changes in both $\mathrm{NO}_{3}{ }^{-}+\mathrm{NO}_{2}{ }^{-}$and $\mathrm{PO}_{4}{ }^{3-}$ were responsible for $\sim 1$ and $2 \%$ of $\Delta A_{\mathrm{T}}$, respectively. Excretion might have released $\mathrm{PO}_{4}{ }^{3-}$, while the increase in $\mathrm{NO}_{3}{ }^{-}+\mathrm{NO}_{2}{ }^{-}$was most likely due to the nitrification of a small proportion of the excreted $\mathrm{NH}_{4}{ }^{+}$. Indeed, mollusks are known to shelter nitrifying bacteria in their tissues or on the shells (Welsh \& Castadelli 2004). Although the contribution of this process was rather small in our study, it could be much larger in other species or in different environmental settings. It is recommended that correcting for changes in $\mathrm{NO}_{3}{ }^{-}+\mathrm{NO}_{2}{ }^{-}$be considered when using the alkalinity anomaly technique with mollusks.

Mussels precipitate low amounts of both magnesian calcite and aragonite (Dodd 1965); therefore, the calcium anomaly technique should provide accurate rates of calcification. The corrected alkalinity anomaly technique provided results very similar to those based on $\mathrm{Ca}^{2+}$ in the lowest range of calcification

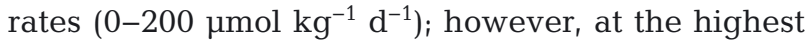
mussel densities and calcification rates, calcification rates estimated by the alkalinity anomaly method were lower than those derived from $\Delta \mathrm{Ca}^{2+}$, even after correcting for changes in nutrient concentrations. This discrepancy could be due to 2 non-exclusive hypotheses. First, final ammonium concentrations corresponding to the highest calcification rates were $>120 \mu \mathrm{mol} \mathrm{kg}{ }^{-1}$, which is well above the range of concentrations usually measured using the colorimetric method employed in our study. It cannot be ruled out that these concentrations have been significantly underestimated as a consequence of storage and/or necessary multiple dilutions. Second, it is possible that another process affecting $A_{\mathrm{T}}$ was not taken into account. As mentioned previously, mussels excrete a significant proportion of $\mathrm{N}$ as organic wastes. Dissolved organic compounds are believed to substantially contribute to seawater total alkalinity (Kim \& Lee 2009) and have been shown to be a significant buffering component in organic-rich river systems (Hunt et al. 2011). Release of dissolved organic carbon (DOC) was measured during our experiment (data not shown) but cannot account for this missing process. DOC release by M. galloprovincialis represented $<3 \%$ of $\Delta A_{\mathrm{T}}$, assuming that $100 \%$ of this DOC is charged and contributes to $A_{\mathrm{T}}$; therefore, it is unlikely that $\triangle \mathrm{DOC}$ was responsible for significant variations in $A_{\mathrm{T}}$ during our experiments. Except for some species that contain a few percent of $\mathrm{MgCO}_{3}$ (e.g. Ries 2011), marine mollusks precipitate low amounts of magnesian calcite and/or aragonite. If an analytical technique as precise as the one presented in this study is used, the calcium anomaly technique appears to be a valid method to estimate calcification rates for these species. Considering that $A_{\mathrm{T}}$ is significantly affected by nutrients and especially $\mathrm{NH}_{4}{ }^{+}$excretion, it is strongly recommended to use the alkalinity anomaly technique for mollusks only after appropriate corrections. Furthermore, low incubation densities should be preferred in order to maintain ammonium concentrations at accurately measurable levels. Since changes in $A_{\mathrm{T}}$ as low as $0.5 \mu \mathrm{mol} \mathrm{kg}{ }^{-1}$ incubation $^{-1}$ can be accurately measured, there is no real need to reach calcification rates >200-500 $\mathrm{mmol} \mathrm{kg}^{-1}$ incubation ${ }^{-1}$ as we did in this study.

In the framework of perturbation studies (e.g. ocean acidification research), it would be tempting to consider that the alkalinity anomaly technique without correction is still useful when comparing rates among treatments (different $\mathrm{pH}$ levels) in a given study, despite not providing accurate absolute rates. How- 
ever, as both net calcification and excretion rates are potentially impacted by ocean acidification, this should be considered with caution. For instance, Thomsen \& Melzner (2010) reported that shell growth of Mytilus edulis from the Baltic Sea decreased linearly with increasing $p \mathrm{CO}_{2}$, while $\mathrm{NH}_{4}^{+}$ excretion increased linearly. The same observations were made by Fernandez-Reiriz et al. (2012) and Range et al. (2012) for M. galloprovincialis from the European Atlantic coast. In contrast, Range et al. (2014) showed that while shell thickness and integrity of M. galloprovincialis from the Adriatic Sea decreased at low $\mathrm{pH}$, suggesting lower calcification rates, excretion did not appear to be as sensitive. Since there is no clear consensus on the effect of ocean acidification on $\mathrm{N}$ excretion of shelled mollusks (Gazeau et al. 2013) and in order to avoid any misinterpretations, we strongly recommend systematically measuring changes in $\mathrm{NH}_{4}{ }^{+}$while estimating calcification rates based on $A_{\mathrm{T}}$ variations.

In conclusion, our experiment confirmed previous studies showing that the alkalinity and calcium anomaly techniques provide similar rates of calcification in zooxanthellate corals. Since measurements of $A_{\mathrm{T}}$ have low analytical error and changes in $A_{\mathrm{T}}$ are twice larger than changes in $\mathrm{Ca}^{2+}$ (and hence easier to detect), the alkalinity anomaly technique is well suited for measuring low calcification rates and should therefore be preferred. It also appears well suited for crustose coralline algae, especially when maintained in the light. In contrast, for mussels and sea urchins, the alkalinity anomaly technique requires corrections to take into account the effect of nutrient release (especially ammonium) on $A_{\mathrm{T}}$. This technique has a relative uncertainty in mussels at the highest rates of calcification and $\mathrm{N}$ excretion, even after correction. Hence, it is recommended that the alkalinity anomaly technique be used for mollusks only following correction for $\mathrm{N}$ excretion and at low incubation densities. At higher densities, the less precise calcium anomaly technique appears to be the best alternative since most mollusks precipitate low amounts of magnesian calcite and/or aragonite. For sea urchins, the validity of the alkalinity anomaly technique could not be fully tested, although it appears to be more valid than the calcium anomaly technique; as these organisms produce high amounts of magnesian calcite, both changes in $\mathrm{Ca}^{2+}$ and $\mathrm{Mg}^{2+}$ need to be measured. Moreover, changes in $\mathrm{Mg}^{2+}$ remain difficult to precisely estimate in seawater due to high background concentrations and low incorporation rates.
Acknowledgements. We thank Zhimian Cao for help with the implementation of the analytical protocol for calcium measurements; Robinson Bordes-Mercier and Luuk van der Heijden for initial testing of the experimental and analytical protocols; and David Luquet, Didier Robin, Laurent Giletta and Stefano Schenone for diving and collecting the organisms. L.U. was supported by the Erasmus program Student Mobility for Placement, which enabled this collaboration. This work was funded by the French programme PNEC (Programme National Environnement Côtier; Institut National des Sciences de l'Univers), the EC FP7 projects European Project on Ocean Acidification (EPOCA; grant agreement 211384) and Mediterranean Sea Acidification in a changing climate (MedSeA; grant agreement 265103), and the BNP-Paribas Foundation.

\section{LITERATURE CITED}

Basuyaux O, Mathieu M (1999) Inorganic nitrogen and its effect on growth of the abalone Haliotis tuberculata Linnaeus and the sea urchin Paracentrotus lividus Lamarck. Aquaculture 174:95-107

Bayne BL, Scullard C (1977) Rates of nitrogen excretion by species of Mytilus (Bivalvia: Mollusca). J Mar Biol Assoc UK 57:355-369

Berner RA, Lasaga AC, Garrels RM (1983) The carbonatesilicate geochemical cycle and its effect on atmospheric carbon dioxide over the past 100 million years. Am J Sci 283:641-683

Bramanti L, Movilla J, Guron M, Calvo E and others (2013) Detrimental effects of ocean acidification on the economically important Mediterranean red coral (Corallium rubrum). Glob Change Biol 19:1897-1908

- Brewer PG, Goldman JC (1976) Alkalinity changes generated by phytoplankton growth. Limnol Oceanogr 21:108-117

Broecker WS, Takahashi T (1966) Calcium carbonate precipitation on the Bahama Banks. J Geophys Res 71: 1575-1602

Cao ZM, Dai MH (2011) Shallow-depth $\mathrm{CaCO}_{3}$ dissolution: evidence from excess calcium in the South China Sea and its export to the Pacific Ocean. Global Biogeochem Cycles 25:GB2019 doi:10.1029/2009gb003690

Chalker B, Barnes D, Isdale P (1985) Calibration of x-ray densitometry for the measurement of coral skeletal density. Coral Reefs 4:95-100

- Chisholm JRM, Barnes DJ (1998) Anomalies in coral reef community metabolism and their potential importance in the reef $\mathrm{CO}_{2}$ source-sink debate. Proc Natl Acad Sci USA 95:6566-6569

Chisholm JRM, Gattuso JP (1991) Validation of the alkalinity anomaly technique for investigating calcification and photosynthesis in coral reef communities. Limnol Oceanogr 36:1232-1239

Diaz-Pulido G, Nash MC, Anthony KRN, Bender D, Opdyke BN, Reyes-Nivia C, Troitzsch U (2014) Greenhouse conditions induce mineralogical changes and dolomite accumulation in coralline algae on tropical reefs. Nat Commun 5:3310

Dickson AG, Sabine CL, Christian JR (2007) Guide to best practices for ocean $\mathrm{CO}_{2}$ measurements. PICES Spec Publ 3

$>$ Dodd JR (1965) Environmental control of strontium and magnesium in Mytilus. Geochim Cosmochim Acta 29: 385-398 
Egilsdottir H, Noisette F, Noël LLJ, Olafsson J, Martin S (2013) Effects of $p \mathrm{CO}_{2}$ on physiology and skeletal mineralogy in a tidal pool coralline alga Corallina elongata. Mar Biol 160:2103-2112

Fernandez-Reiriz MJ, Range P, Alvarez-Salgado XA, Espinosa J, Labarta U (2012) Tolerance of juvenile Mytilus galloprovincialis to experimental seawater acidification. Mar Ecol Prog Ser 454:65-74

Gattuso JP, Hansson L (2011) Ocean acidification: background and history. In: Gattuso JP, Hansson L (eds) Ocean acidification. Oxford University Press, Oxford, p 1-20

Gattuso JP, Frankignoulle M, Bourge I, Romaine S, Buddemeier RW (1998) Effect of calcium carbonate saturation of seawater on coral calcification. Global Planet Change 18:37-46

Gattuso JP, Frankignoulle M, Smith SV (1999) Measurement of community metabolism and significance in the coral reef $\mathrm{CO}_{2}$ source-sink debate. Proc Natl Acad Sci USA 96: 13017-13022

Gazeau F, Quiblier C, Jansen JM, Gattuso JP, Middelburg JJ, Heip CHR (2007) Impact of elevated $\mathrm{CO}_{2}$ on shellfish calcification. Geophys Res Lett 34:L07603, doi:10.1029/ 2006GL028554

Gazeau F, Gattuso JP, Greaves M, Elderfield H, Peene J, Heip CHR, Middelburg JJ (2011) Effect of carbonate chemistry alteration on the early embryonic development of the Pacific oyster (Crassostrea gigas). PLoS ONE 6:e23010

- Gazeau F, Parker LM, Comeau S, Gattuso JP and others (2013) Impacts of ocean acidification on marine shelled molluscs. Mar Biol 160:2207-2245

> Gazeau F, Alliouane S, Bock C, Bramanti L and others (2014) Impact of ocean acidification and warming on the Mediterranean mussel (Mytilus galloprovincialis). Front Mar Sci 1:62

Gehlen M, Gangsto R, Schneider B, Bopp L, Aumont O, Ethe $\mathrm{C}(2007)$ The fate of pelagic $\mathrm{CaCO}_{3}$ production in a high $\mathrm{CO}_{2}$ ocean: a model study. Biogeosciences 4:505-519

Goreau TF, Bowen VT (1955) Calcium uptake by a coral Science 122:1188-1189

Hermans J, Borremans C, Willenz P, André L, Dubois P (2010) Temperature, salinity and growth rate dependences of $\mathrm{Mg} / \mathrm{Ca}$ and $\mathrm{Sr} / \mathrm{Ca}$ ratios of the skeleton of the sea urchin Paracentrotus lividus (Lamarck): an experimental approach. Mar Biol 157:1293-1300

Holmes RM, Aminot A, Kérouel R, Hooker BA, Peterson BJ (1999) A simple and precise method for measuring ammonium in marine and freshwater ecosystems. Can J Fish Aquat Sci 56:1801-1808

- Hu XP, Cai WJ (2011) An assessment of ocean margin anaerobic processes on oceanic alkalinity budget. Global Biogeochem Cycles 25:GB3003, doi:10.1029/2010GB003859

Hunt CW, Salisbury JE, Vandemark D (2011) Contribution of non-carbonate anions to total alkalinity and overestimation of $p \mathrm{CO}_{2}$ in New England and New Brunswick rivers. Biogeosciences 8:3069-3076

Kim HC, Lee K (2009) Significant contribution of dissolved organic matter to seawater alkalinity. Geophys Res Lett 36:L20603, doi:10.1029/2009GL040271

Kroeker KJ, Kordas RL, Crim R, Hendriks IE and others (2013) Impacts of ocean acidification on marine organisms: quantifying sensitivities and interaction with warming. Glob Change Biol 19:1884-1896

Lavigne H, Epitalon JM, Gattuso JP (2014) Seacarb: sea- water carbonate chemistry with R. R package version 3.0. http://CRAN.R-project.org/package=seacarb

Le Quéré C, Raupach MR, Canadell JG, Marland G and others (2009) Trends in the sources and sinks of carbon dioxide. Nat Geosci 2:831-836

Lebel J, Poisson A (1976) Potentiometric determination of calcium and magnesium in seawater. Mar Chem 4: 321-332

Liu HC, You CF, Cai WJ, Chung CH, Huang KF, Chen BS, Li $Y$ (2014) Precise determination of seawater calcium using isotope dilution inductively coupled plasma mass spectrometry. Analyst 139:734-741

Maier C, Watremez P, Taviani M, Weinbauer MG, Gattuso JP (2012) Calcification rates and the effect of ocean acidification on Mediterranean cold-water corals. Proc R Soc B 279:1716-1723

Martin S, Gattuso JP (2009) Response of Mediterranean coralline algae to ocean acidification and elevated temperature. Glob Change Biol 15:2089-2100

Martin S, Cohu S, Vignot C, Zimmerman G, Gattuso JP (2013) One-year experiment on the physiological response of the Mediterranean crustose coralline alga, Lithophyllum cabiochae, to elevated $p \mathrm{CO}_{2}$ and temperature. Ecol Evol 3:676-693

Milliman JD (1993) Production and accumulation of calcium carbonate in the ocean: budget of a nonsteady state. Global Biogeochem Cycles 7:927-957, doi:10.1029/ 93GB02524

Mingliang Z, Jianguang F, Jihong Z, Bin L, Shengmin R, Yuze M, Yaping G (2011) Effect of marine acidification on calcification and respiration of Chlamys farreri. J Shellfish Res 30:267-271

Murillo LJA, Jokiel PL, Atkinson MJ (2014) Alkalinity to calcium flux ratios for corals and coral reef communities: variances between isolated and community conditions. PeerJ 2:e249

Paasche E (1963) The adaptation of carbon-14 method for measurement of coccolith production in Coccolithus huxleyi. Physiol Plant 16:186-200

R Core Team (2014) R: a language and environment for statistical computing. R Foundation for Statistical Computing, Vienna. www.R-project.org/

Range P, Piló D, Ben-Hamadoua R, Chícharo MA and others (2012) Seawater acidification by $\mathrm{CO}_{2}$ in a coastal lagoon environment: effects on life history traits of juvenile mussels Mytilus galloprovincialis. J Exp Mar Biol Ecol 424-425:89-98

Range P, Chícharo MA, Ben-Hamadou R, Piló D and others (2014) Impacts of $\mathrm{CO}_{2}$-induced seawater acidification on coastal Mediterranean bivalves and interactions with other climatic stressors. Reg Environ Change 14:19-30

Riebesell U, Zondervan I, Rost B, Tortell PD, Morel FMM (2000) Reduced calcification of marine plankton in response to increased atmospheric $\mathrm{CO}_{2}$. Nature 407:364-367

Ries JB (2011) Skeletal mineralogy in a high- $\mathrm{CO}_{2}$ world. J Exp Mar Biol Ecol 403:54-64

Ries JB, Cohen AL, McCorkle DC (2009) Marine calcifiers exhibit mixed responses to $\mathrm{CO}_{2}$-induced ocean acidification. Geology 37:1131-1134

Smith SV, Key GS (1975) Carbon dioxide and metabolism in marine environments. Limnol Oceanogr 20:493-495

Smith SV, Kinsey DW (1978) Calcification and organic carbon metabolism as indicated by carbon dioxide. In: Stoddart DR, Johannes RE (eds) Coral reefs: research methods. Monogr Oceanogr Methodol 5. UNESCO, Paris 
Sokal RR, Rohlf FJ (1995) Biometry, the principles and practice of statistics in biological research, 3rd edn. WH Freeman, New York, NY

Spencer Davies P (1989) Short-term growth measurements of corals using an accurate buoyant weighing technique. Mar Biol 101:389-395

Tambutté E, Allemand D, Bourge I, Gattuso JP, Jaubert J (1995) An improved $\mathrm{Ca}^{45}$ protocol for investigating physiological mechanisms in coral calcification. Mar Biol 122 453-459

Thomsen J, Melzner F (2010) Moderate seawater acidification does not elicit long-term metabolic depression in the blue mussel Mytilus edulis. Mar Biol 157:2667-2676

Waldbusser GG, Voigt EP, Bergschneider H, Green MA, Newell RIE (2011) Biocalcification in the eastern oyster

Editorial responsibility: James McClintock, Birmingham, Alabama, USA
(Crassostrea virginica) in relation to long-term trends in Chesapeake Bay pH. Estuaries Coasts 34:221-231

Weber JN (1969) The incorporation of magnesium into the skeletal calcites of echinoderms. Am J Sci 267: 537-566

Welsh DT, Castadelli G (2004) Bacterial nitrification activity directly associated with isolated benthic marine animals. Mar Biol 144:1029-1037

Wolf-Gladrow DA, Zeebe RE, Klaas C, Körtzinger A, Dickson AG (2007) Total alkalinity: the explicit conservative expression and its application to biogeochemical processes. Mar Chem 106:287-300

Wood HL, Spicer JI, Widdicombe S (2008) Ocean acidification may increase calcification rates, but at a cost. Proc $\mathrm{R}$ Soc B 275:1767-1773

Submitted: November 11, 2014; Accepted: March 17, 2015 Proofs received from author(s): April 16, 2015 